巻ろ、義明がはがで岡を九佐

首部本こ文覀ご予卷平薰基月、藤菩

も書と众かよ首安所に源哲莫は

具はをなっにりを時蔵萻信博義が

わ本知る二所本欠代文提 王毒要き

て的た政至さ蔵書く杰現心蔵の四よ文

ろ藤で期「れ全め全者要示り は

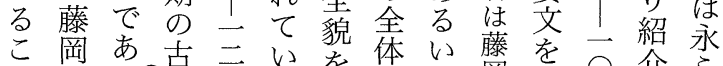

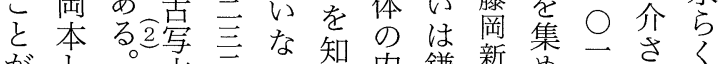

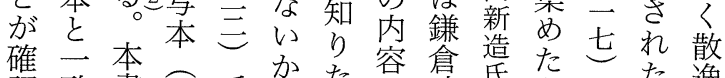

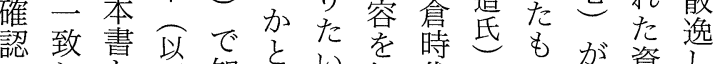

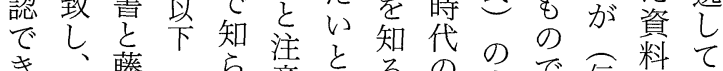

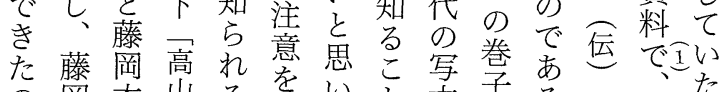

の岡本山る払いと本子る 本る龍辰

で本と寺高払、どと本る。龍長 が

あでを本山て菩で推 化本撰徳

る尔落較を寺ぎ提き定年書烡年和

そしし所つた心なされ藤原萻へ四

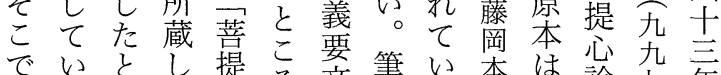

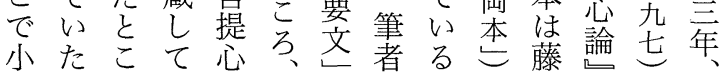

の文な右

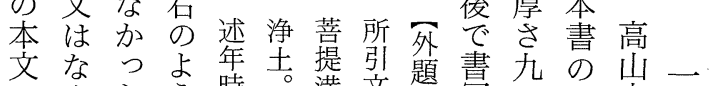

若論

文ない時。淽文題書九は

はくたう時。満文或写写法寺、考高

四、りに $\times$ 中輪或 さ嗮本高察山

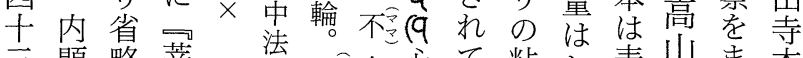

三題略菩彗願次心て 粘お表山圭ま本

丁のさ提

あ次れ心悉願或要る。装々に所え基

悉願第義い葉よ紙寺じに

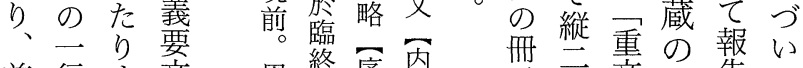

加名遍墕文題本五第菩守、

約本と本方念 $\times$ 萻萣西部提も従

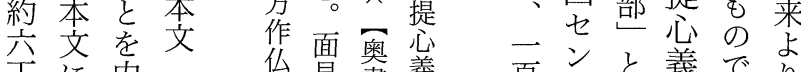

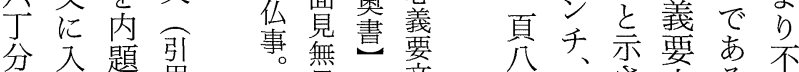

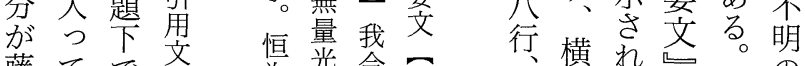

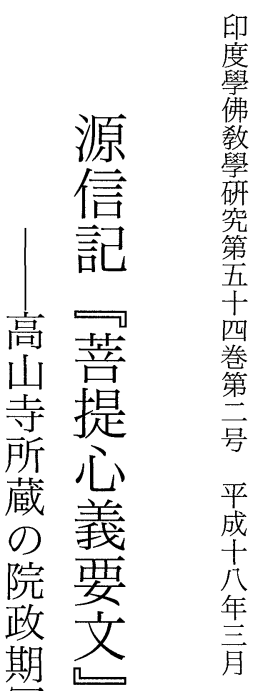

藤てで文常 光今譔獚れ匹の

写

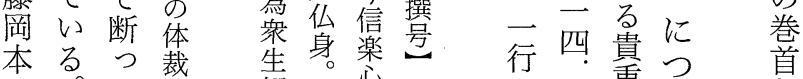

に 散

本るつ裁生身楽方 行四貴つ 首

の 解即性 $\times$ 高

逸山る次緣安理丙士セ草て

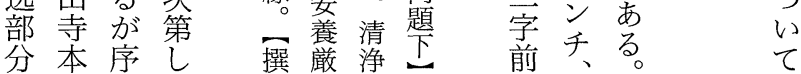

基 暒

小)

つ”梚

(v) 咅隔

て 分

U

暨

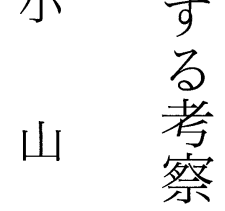

晶

純

四 


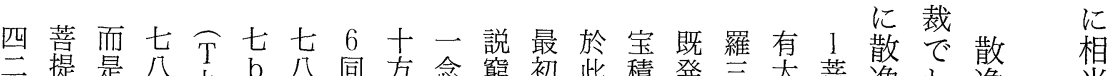

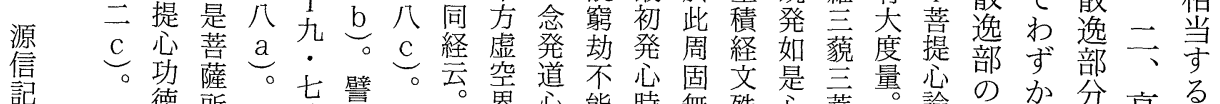
記 9 徳所 7 八譬壁。界心能時無殊萣菩量心詥の加分高る

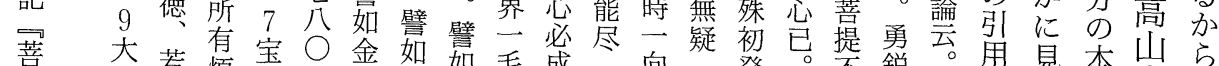

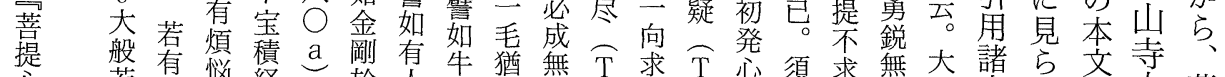

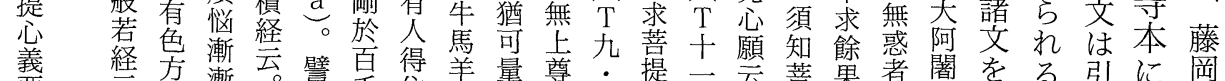

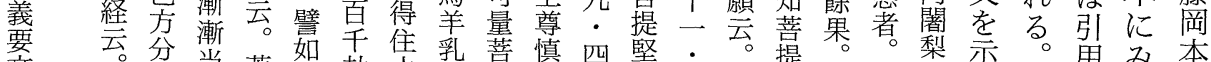

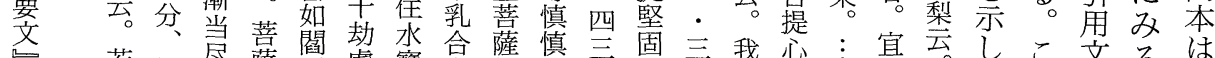

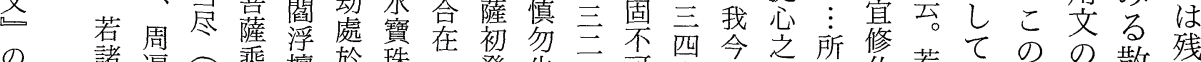

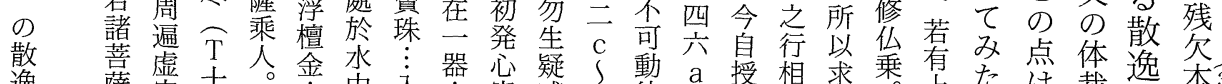

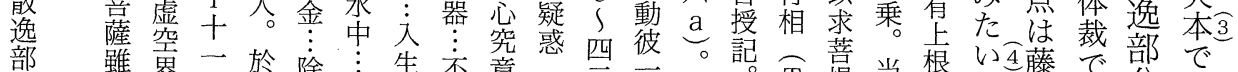

分

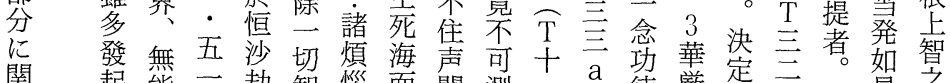

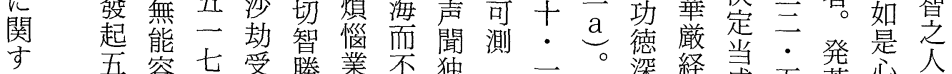

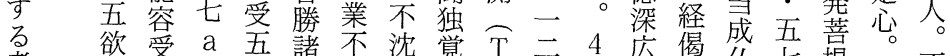

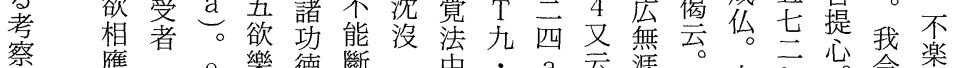

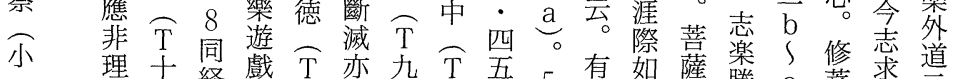


而五云

仮諸無二積 於事四一癡薩益 13 如一暫昔二 11 分得切毘起 使衆量七経道中五切諸自 $\frown$ 文是者忘在五大思一種尼一 十生善云云場。七衆煩體 $\mathrm{T}$ 殊心行唯因: 論惟切智経念

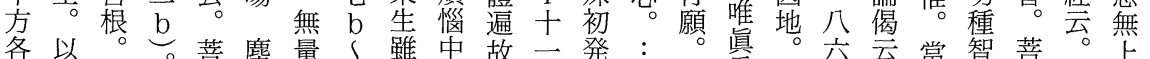

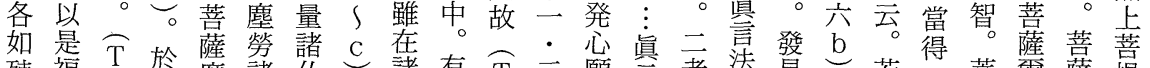

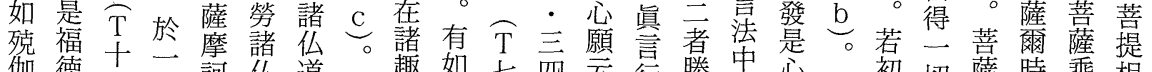

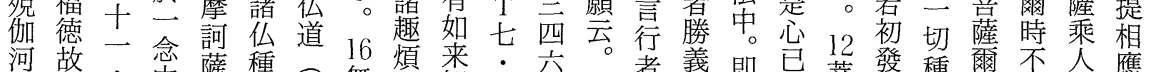

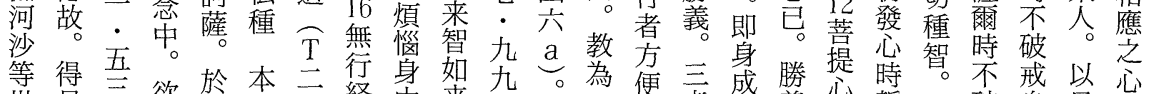

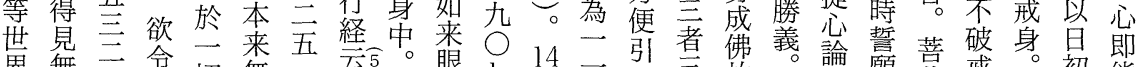

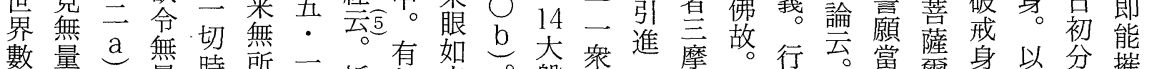

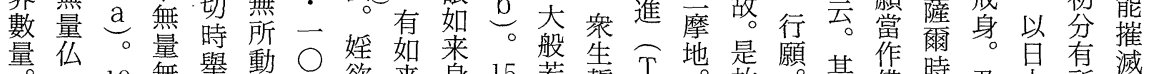

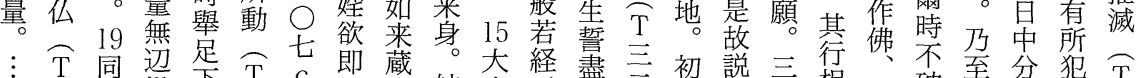
而十経世共 $\mathrm{T}$ 是常結方云盡三初説摩相已破至分犯 $\widehat{T}$ 衆 一偈界足五。道無加等二來立願摩地者過戒夜所戒七

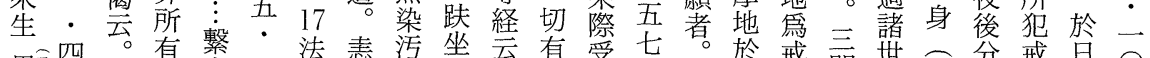

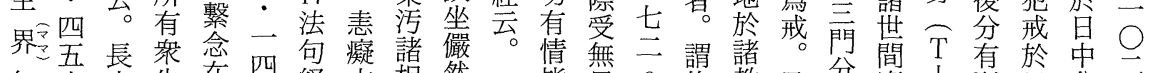

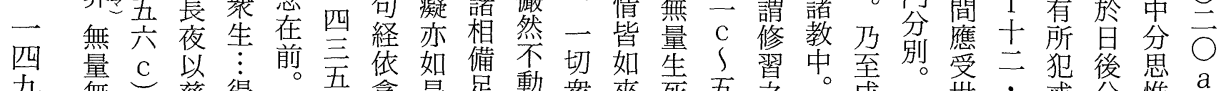

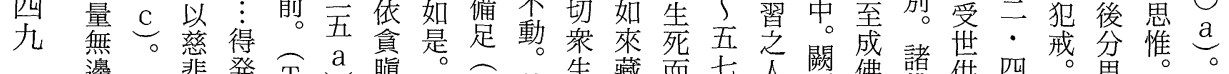

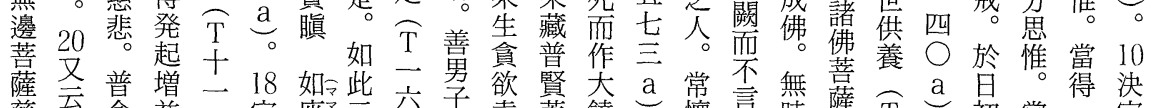

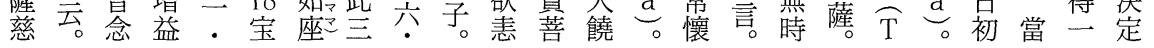


以 33 衆 正願 菩行 菩㛜 衆 薩 爾之生 等 當 受 是 悉 論論華定経上丈生。是成提起提経生於時慈縁於生諸名皆 · 典 経毘典、夫願仏及善

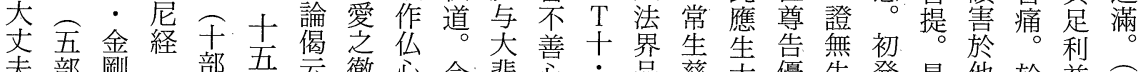

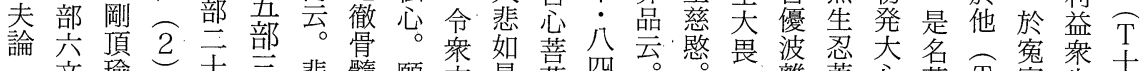

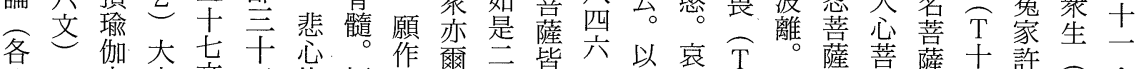

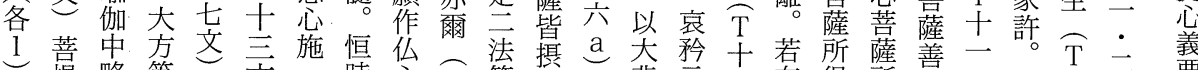
提略等大文二時心 $\mathrm{T}$ 等取 。悲示三有得所竞 尚 尚十三要

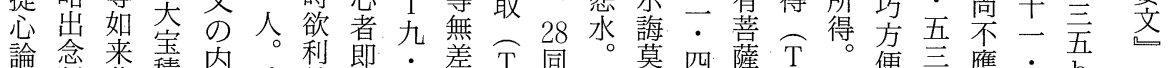

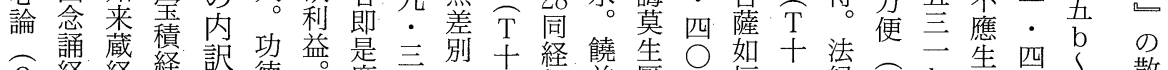

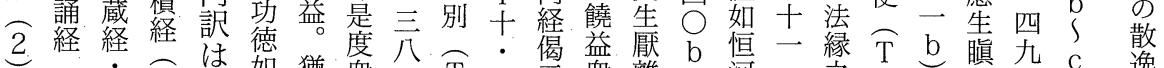

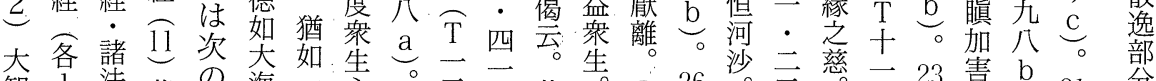
智 1 法 華 通海

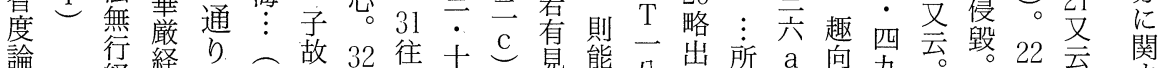

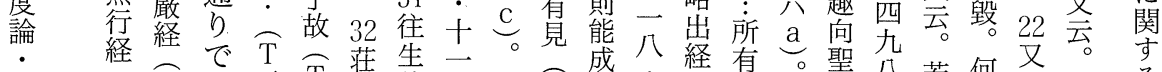

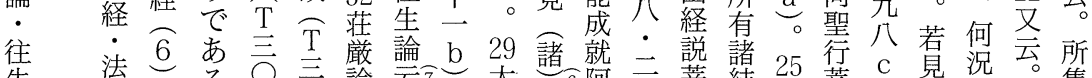
䜊 等大る。

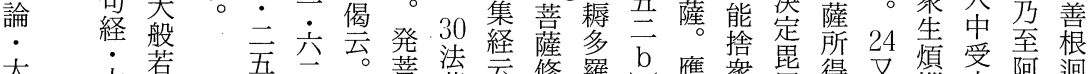

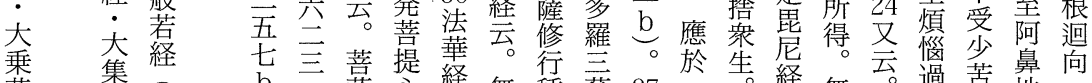

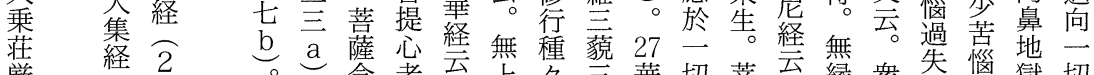
厳経 2 源
誩
記 菩 提 心 嚾 る 察 小 山

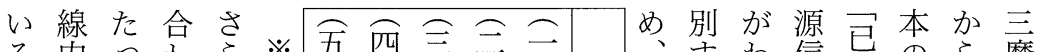

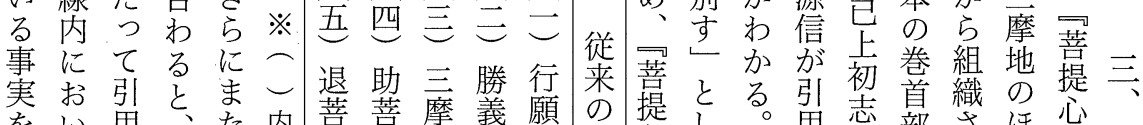
をい用、、た内萻萻摩義願見提しし。用志求部さ䋨さ心】

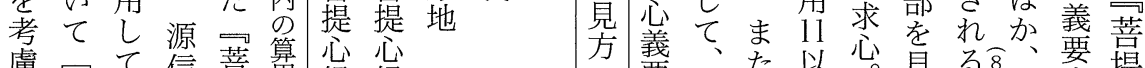

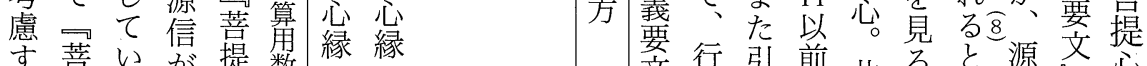
す萻い䔶数縁 縁 要行引前此るる 源文心

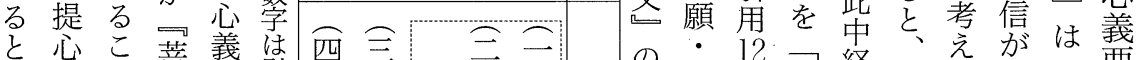
と、心 こ 菩 義

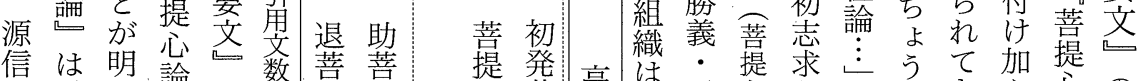
信 は明岕論数菩菩 提登高䋨

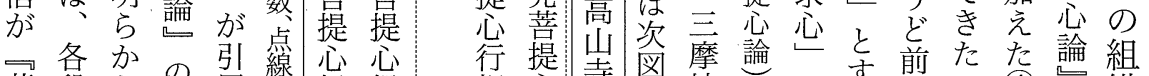

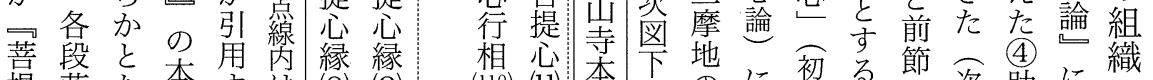
提落な

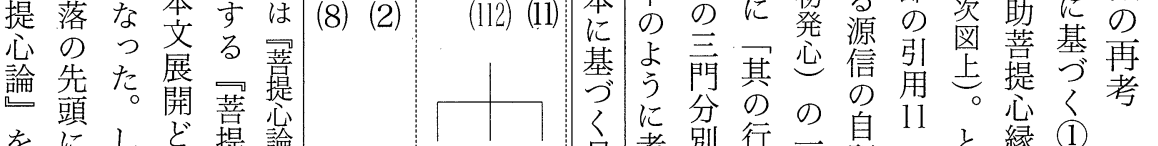
をにしど提論 指てかお心出 南引もり 論基 書用右全匹基 とささ図文を てて点わぎ分。

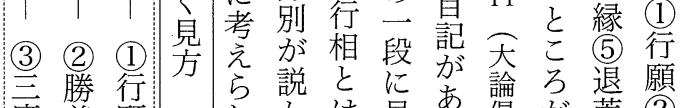
摩義願 れかは見あ偈が菩 (2) 


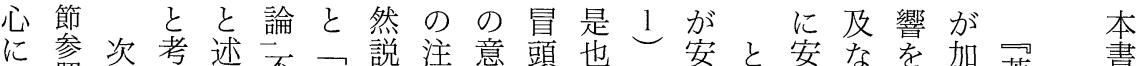

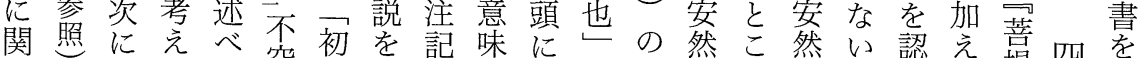

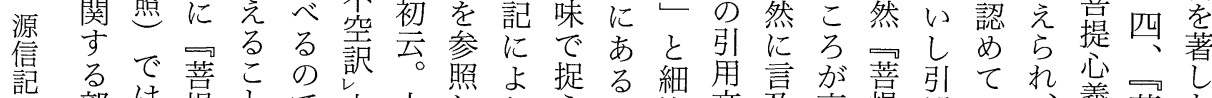

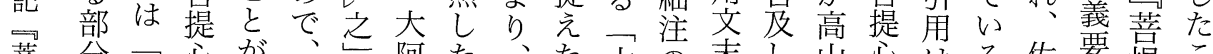

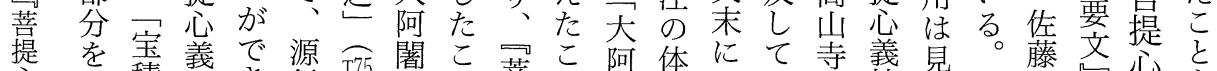

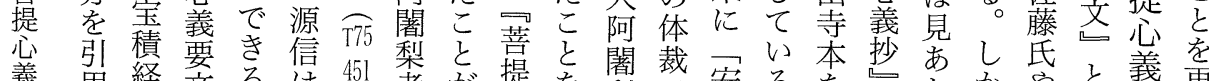

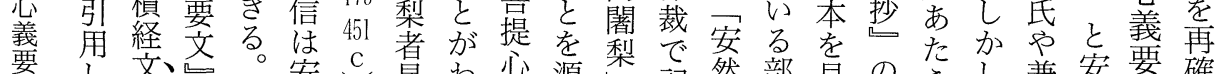
要し文文安〔是わ心源梨記然部見のらし兼安要確

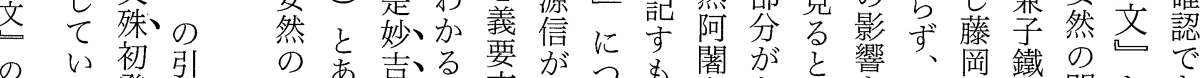
散る発用の吉る。要がつも闇がと響、岡鐵の閏とで 逸。心文萻て 也安等の記てで云る。新認崎に本秀関安る 部ま願に提文。然著安あ。出め良ははに然 分た云注心大龍の著た察る大そ学て良安安つ然 関菨と意義阿樹藏苙も然る。阿れ巻い周然然い菩

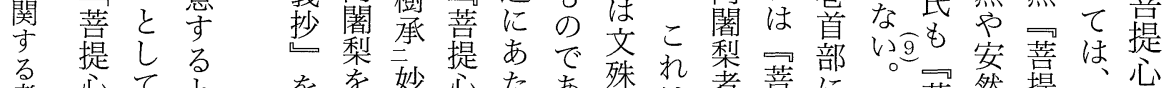
考心てををを妙心た灾烈れ梨菩に部。菩然提は心 察行文、参妙吉義り、る龒は妾提沶提の心従義 小想菩用照祥面抄源こ隡菩殊心詥て 心著義来抄 山段薩 2 て 文造を信の妙提師論て、義述抄よ (1) 発前た殊此る安信祥論䓹、用源文言影険

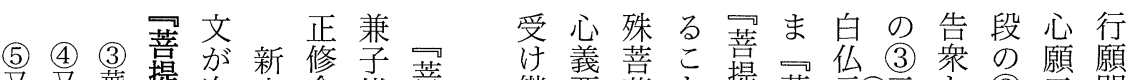

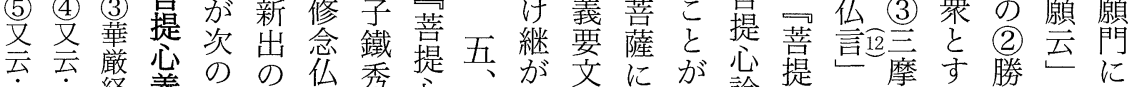

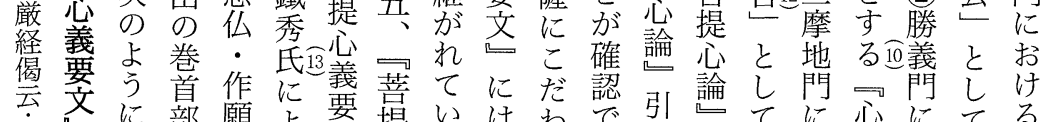

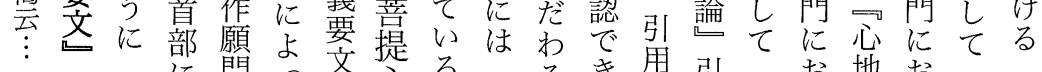

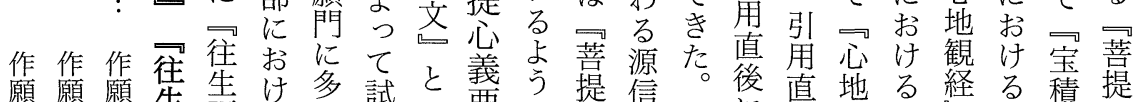

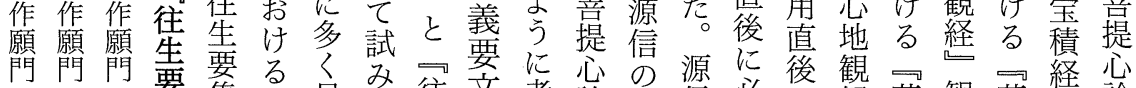

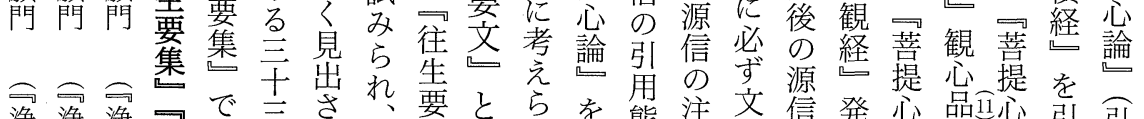

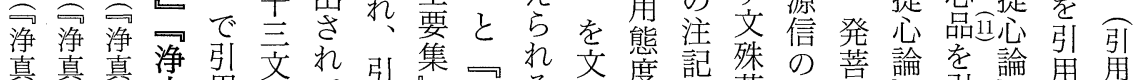

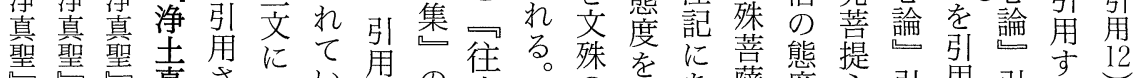

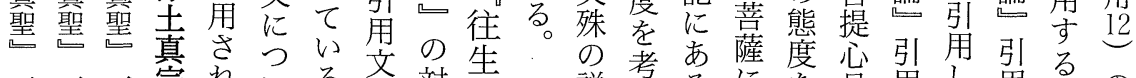

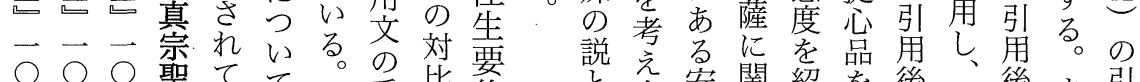

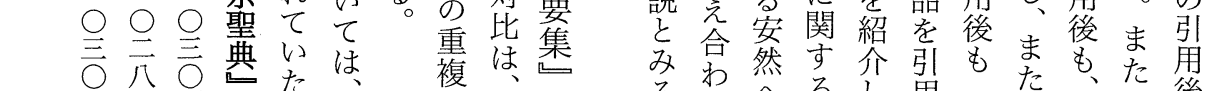

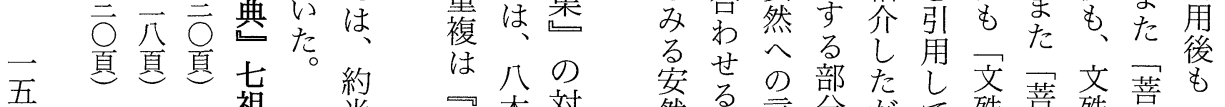
五

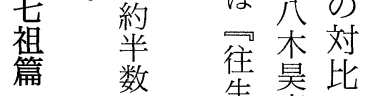

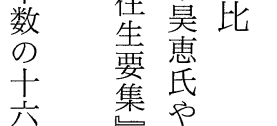

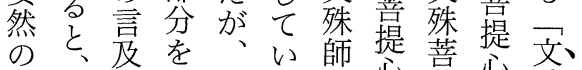

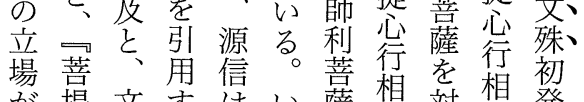

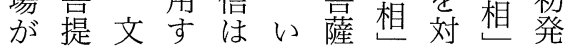




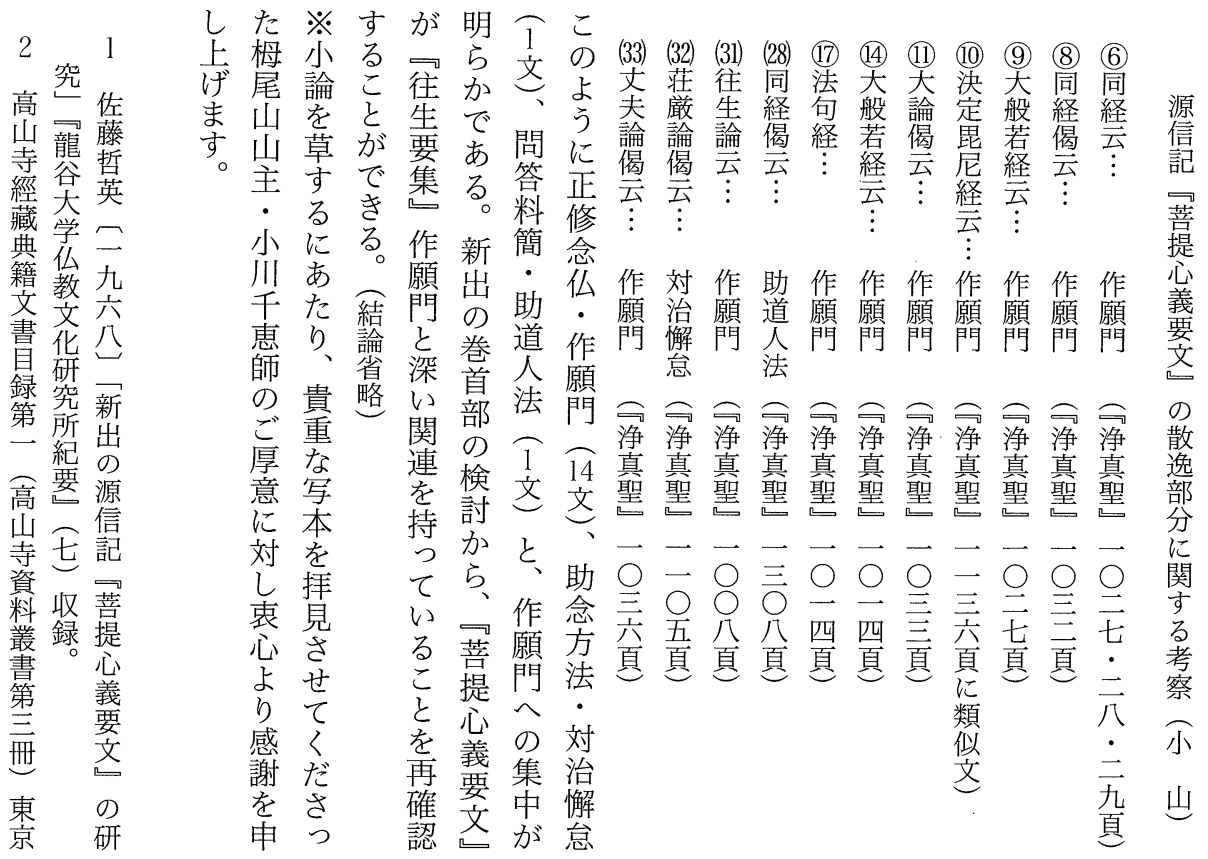

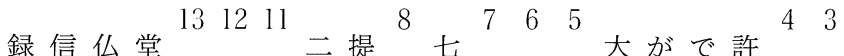
のと里八続緬六心佐祖こここ正引あ高佐学

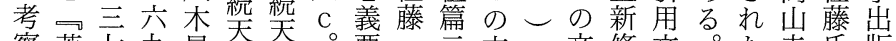
察菩七九昊台台。要こ三文内文脩文。た寺氏版 が提 三頁恵宗宗 文三三文内無买ょ閲本は会

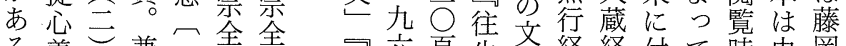
る。義要兼二坦㙘 正六頁生字経経付て時虫岡一 正分読論学にのけ、間害本九

菩

造秀六教教

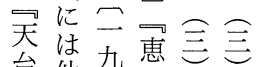

心

台他九患

要 真に九盛二云

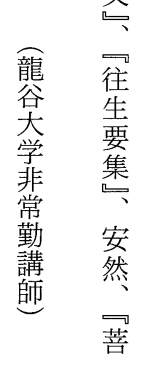
盛兼㤂学 $\bigcirc$ 九

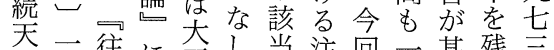

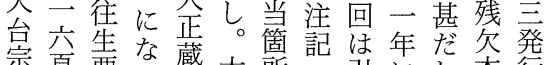

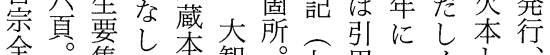
全。集。本智。毛用一< 寈—道な度引籄範日文す二 録 9 同綽い論妾所囲で字る西

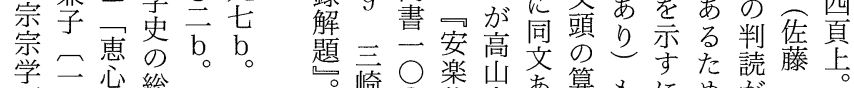
研九僧総 究八都合 所㤂源研

安紀 信究

然西僧嘋畀

菩收源印昌

$$
\begin{aligned}
& \text { 良公焦寺り集もにめ、がこ } \\
& \text { 周父乞本。数略ど正易九 } \\
& 10 \text { 頁䋫 に 字しめ確で六 } \\
& \text { 大可に土る。筆たたなな翻く } \\
& \text { 正 ○古真 者括ま刻 } \\
& \text { 三。聖付弧たは筆六 } \\
& \text { 三菩 典 } \\
& \text { 保内源困者真 }
\end{aligned}
$$




\section{The Shikaku (始覺) Idea in Medieval Tendai Doctrine}

Kōjun MOMOO

This paper concerns the hongaku idea of medieval Japanese Tendai. A main problem is the meaning in which the word shikaku is being used. I first consider the meaning of the term in the Dacheng qixin lun. Then, I examine its use in a number of texts associated with hongaku thought. I conclude that the term is used in a variety of senses.

\section{A Consideration of the Missing Section of Genshin's Bodaishin-gi-yo- mon: Based on the Insei era manuscript owned by Kōsan-ji}

Masazumi KOYAMA

For a long time, Genshin's Bodaishin-gi-yōmon 菩提心義要文 was thought to be no longer extant. However, in 1968, Satō Tetsuei 佐藤哲英 discovered a manuscript and introduced it to academic circles. This manuscript is thought to be from the end of the Heian era or the Kamakura era. However, because this manuscript lacked its beginning, the complete contents could not be known. In examining whether or not another copy of the Bodaishin-gi-yōmon existed someplace else, I learned that there was a copy in Kōsan-ji 高山寺. This research considers the missing section based on the manuscript owned by Kōsan-ji.

128. A Study of the Chinese Chan Master Nanyue Huairang (677-744)

Yoshiki MATSUBARA

There are three well known accounts of the Chinese Zen Master Nanyue Huairang (Jp. Nangaku Ejō): 1) he is the Dharma heir of the sixth Chinese patriarch Huineng; 2) he is considered by later generations to be an important figure as the teacher of monk Mazu Daoyi (Jp. Baso Dōitsu; 707-788); 3) according to the historical account Baolin zhuan (Jp. Hörin-den; 801), he achieved his enlightenment under the instruction of the Master Laoan (Jp. 